\title{
Comparison of Croatian Foreign Language Teachers' General Propensity towards the Use of ICT and Its Impact on the Foreign Language Teaching Process
}

\author{
By Krunoslav Mikulan* \\ Vladimir Legac ${ }^{\dagger}$ \\ Predrag Oreskit
}

In this paper the authors present some of the results of a research into the influence of information and communication technologies (ICT) on foreign language (FL) teaching. The survey was conducted on a sample of 255 FL teachers $(N=255)$ in the Republic of Croatia. The teachers are eployed at primary and secondary schools, or at universities, and they teach six different FLs. The vast majority possess a PC at home and/or work, and have access to the Internet, but less than half teach FLs in classrooms equipped with a computer. The starting hypothesis was that the increase of the time teachers spend on their computers and the Internet would lead to the increase in their ICT competences. The results of the study have confirmed the authors' hypothesis: Correlation quotients have shown that there is a positive statistically significant correlation between the amounts of time spent using ICT and the attitudes of FL teachers regarding their own assessment of competence for the successful application of ICT in the FLs teaching. The analysis of the results presented in the paper mainly focus on correlations between the amount of time spent using ICT and the teachers' self-assessments of their 12 different computer competences and the evaluation of their experience with ICT equipment and software.

Keywords: Educational software, e-learning, self-assessment of ICT competences of Croatian foreign language teachers.

\section{Introduction}

The structure of educational methods and the development of new approaches to education and learning in the 21 st century have become the basis of the contemporary educational system (Selwyn, 2012; Cartelli, 2012; Laurillard, 2012; Price, 2013; Vasbo \& Gudmundsdottir, 2014). The development of creative and collaborative skills of both teachers and students requires an intense merging of various methods of teaching and learning, as well as the changes in the forms of collaboration between teachers and students (Henry, 2014). ICT is often viewed as a potential tool for revolutionizing education which can eventually improve the effects of learning (Johansson \&

\footnotetext{
* Assistant Professor, University of Zagreb, Croatia.

${ }^{\dagger}$ Assistant Professor, University of Zagreb, Croatia.

* Assistant Professor, University of Zagreb, Croatia.
} 
Gärdenfors 2012, Scaife \& Rogers 2012, Underwood 2014), and it can help in creating equal opportunities for attaining education, which can ultimately lead to the transformation of the society as a whole (Kozma, 2011).

With the constant development of new information and communication technologies (ICT), media and new forms of communication, foreign language teachers (FLT) are faced with the problem of becoming acquainted with a variety of devices, applications and software not only because they are used by their students, but also because they could potentially be used in the teaching process. Research into the use of ICT in life and work of teachers has been conducted a number of times (cf. Wu, 2014; Zervas, Chatzistavrianos, \& Sampson, 2014; Light and Pierson, 2014; Brigas et. al., 2016); research that would focus on FLT is less common, but the results are similar no matter in which country the research is conducted (Li \& Walsh, 2011; Cajkler \& Addelman, 2012; Halvorsen, 2016). The researchers agree that the use of ICT in a FL classroom can help create an interactive and immersive learning environment and an authentic language input, but they also regularly express the need of additional training for FLT and the need for them to embrace new teaching practices connected with the use of ICT in education (Vekiri, 2014; Gretter \& Gondra, 2016; Grosbois \& Sarré, 2016; Liu, 2016; Yonemoto, Tsuda, \& Hayashi, 2016).

Education of teachers in developed European countries has been recognized as one of the key social and even political issue and since the 1990s the Council of Europe and the European Union have initiated various projects and given guidelines for models of teacher education in Europe. (Mihaljevic Djigunovic \& Mardesic, 2009). One of the major documents that resulted from those papers is the Green Paper on Teacher Education (2000). According to Mihaljevic Djigunovic (2008) two most important projects that focussed on the development of curricula for the education of FLT in Croatia and the Western Balkans were the Tempus project Foreign Languages at Primary Level and Tuning Educational Structures in Europe and its subdivision: Tuning Teacher Education Curricula in the Western Balkans. Two of the authors of this paper actively took part in the first project, which lasted from 2004-2007.

Teacher's competences could be defined as teacher's knowledge, skills and abilities that are acquired during their pre-service training and probationary year and later maintained and developed through teaching experience and inservice training. According to Radisic et al (2007), there are two basic competence areas for teachers of FLs: subject-specific and educational competences. Educational competences include pedagogical-psychological competences and the competences related to lifelong learning. Subject-specific can be subdivided into the competences related to language and culture and subject-specific teacher competences. The former include teacher's linguistic, sociolinguistic, pragmatic and intercultural competences while the latter include the competences related to general theories of language acquisition and the competences related to the application of the knowledge of modern FL teaching theories. ICT and Multimedia Competences of FLT would be one of the goals belonging to this last competence group. This would mean two 
things. Firstly, that a FLT should be able to systematically foster the development of learners' language skills through a wide variety of activities, teaching materials, tools, aids and technical equipment. Secondly, that a FLT should be able to organise lessons according to the learners' age and the level of their knowledge of FL in which he/she would appropriately and effectively apply modern ICT technology and/or multimedia. According to Mihaljevic Djigunovic (2008) ICT technology and/or multimedia competences are a constituent of technological competences, which are part of the instrumental group of competences belonging to generic teacher competences.

FLT in Croatia, Western Balkans, most European countries and in many other countries in the rest of the world have been using some technological teaching aids to a higher degree than teachers of most other subjects for decades. When personal computers with peripheral devices and interactive whiteboards appeared in Croatia, ICT equipment was very often used only in ICT classrooms and exclusively for ICT lessons. New materials with digital technology for teaching FLs started to appear on the market and teachers were not able to use them appropriately. Legac and Mikulan (2003) were among the first teacher trainers who have pointed to the fact that Croatian higher education institutions do not offer courses in the use of modern technologies so these two authors became strong advocators for the introduction of a course at teacher training colleges and universities that would teach students how to use these new technologies in FL classes and thus eliminate the existing gap.

Engler and Mikulan (2006) emphasized the synergetic potentials whenever ICT technology is appropriately used in FL classrooms, and Mikulan (2008) defined and divided multimedia competences of primary FLT. According to Mikulan (2008) they can be divided into three large groups: 1) theoretical competences, 2) organizational and social competences, and 3) practical competences. The third group is subdivided into a) Internet resources for FLTs and students, b) specific use of new technologies for FL teaching, c) specific use of non-language teaching software in the teaching process, and d) FL teaching/learning software.

The authors of this paper were interested in investigating how Croatian FLTs assess some of their general and special ICT competences, how they use ICT equipment at their homes and schools, what their propensity is towards the use of ICT, and what is its impact on the FL process. The results of the study are presented in this paper.

\section{Methodology}

\section{Aim of Study}

The aims of this study were the following: 
a. to find out whether or not FL teachers are well equipped with ICT technology at home and at their schools or institutions of higher education,

b. to learn about their ICT daily practices,

c. to explore the self-assessments of their general ICT competences and their special ICT competences for FL teaching,

d. to get an insight into the relationship between their time spent on the computer and the Internet, and their ICT competences, and

e. to get feedback from FL teachers about their experience with ICT equipment in FL teaching.

The authors' starting hypothesis was that the increase of the time teachers spend on their computers and the Internet would lead to the increase in their ICT competences.

\section{Instrument}

Only one instrument was used in the study. It was a self-constructed, anonymous, online questionnaire in Croatian consisting of several sections. The first section was a general teacher profile form containing four items, of which three were obligatory and one was optional. The optional item asked the participants to mark their gender. The obligatory items asked the participants to specify the type of school, which foreign language or languages they teach and whether at the time of data collection they were teaching in a state or private school.

The second section inquired into general ICT equipment at home and at school/college/university. There were ten main items in this section which had additional sub items. Teachers were asked whether or not they possessed a computer at home and at school, whether or not computers were available in every language classroom and whether or not they had access to the Internet there. If they answered those ten questions affirmatively, then they were additionally asked whether they and their students had to share their computer/tablet/laptop with somebody else and with how many persons. They were also asked to specify the percentage of classrooms where computers, projectors and the Internet were available. Additionally the questionnaire asked teachers how satisfied they were with the co-operation of their administrators if they existed in their institutions and with the quality of the Internet connections. The items dealing with teachers' satisfaction were all 5-point Likert scale type questions.

The third section looked into the teachers' general ICT competences. It contained six items. Teachers were first asked to answer whether or not they had been instructed to use computers. This question was followed by five 5point Likert scale items where they had to assess their competences in using computers to: 
a. edit texts (Word and Excel),

b. seek information and to work with and distribute information (searching the web, creating folders...),

c. create and exchange information (e-mail, chat, creating personal webpages),

d. present information (PowerPoint),

e. create teaching materials (Moodle and similar ones), and

f. monitor students' progress.

The $4^{\text {th }}$ section tried to get an insight into teachers' special ICT competences for FL teaching. It consisted of seven items. The first item was a yes-no question asking teachers whether or not they had attended a course or whether or not they had been instructed to use computers to teach FLs. It was followed by six 5-point Likert scale items asking teachers to assess their competences:
a. in using FL education software,
b. in using computers for creation of multifunctional exercises and tests,
c. in using computer software for distance and e-learning,
d. in using ICT for creation of authentic FL environment,
e. in using ICT for adoption of correct pronunciation, and
f. in using computer games for FL learning.

The $5^{\text {th }}$ section looked at the average daily time teachers spend on the computer, the Internet and the mobile phone. There were six items in this section. In each item teachers had to circle the number of hours. The following answers were offered:
a. less than an hour,
b. one hour,
c. two hours,
d. three hours,
e. four hours,
f. five hours,
g. six hours,
h. seven hours,
i. eight hours, and
j. more than eight hours.

The $6^{\text {th }}$ section was an inquiry into teachers' experience into their work and use of ICT equipment in FL teaching. The section consisted of ten 5-point Likert scale items. In each of them teachers had to assess: 
a. their classroom management when using ICT equipment and software while teaching,

b. efficiency of feedback for students when ICT equipment and software are used,

c. the increase of students' self-confidence in FL use when ICT equipment and software are used,

d. the lowering of students' language anxiety when ICT equipment and software are used,

e. the increase in students' desire to learn FLs and their curiosity about FLs,

f. the increase in students' desire for real communication with interlocutors in FL,

g. their experience in using ICT equipment, software and online dictionaries for the acquisition of FL vocabulary,

h. the increase in students' usage of FL structures when ICT equipment and software are used,

i. the improvement of students' pronunciation when ICT equipment and software are used, and

j. the improvement of students' knowledge when ICT equipment and software are used.

At the end of the questionnaire, teachers could leave their comments for the authors of the survey.

\section{Participants}

Research was carried out among 255 teachers of FLs. 22 of them (8.6\%) were men and $233(91.4 \%)$ were women. These percentages reflect the reality, as for well over half of the century over $90 \%$ of the university students studying to become FLTs have been women. The vast majority of them $(93.3 \%)$ were employees in state schools or institutions of higher education, whereas the rest were mainly employed in private institutions or at the time of data collection were teaching partly in state and partly in private institutions. At the time of data collection some of the respondents were teaching in primary and secondary schools, or in some other combination. Croatian primary school lasts for eight years and is divided into the so-called lower grades (Grades 1-4) and upper grades (Grades 5-8). Secondary school students can choose between 4-year grammar schools and 3-4 year vocational and technical schools. Therefore, neither does the sum of individual components of the distribution of teachers in percentages equal 100, (it is more than that), nor does the sum of the individual numbers of teachers equal 255 (for the same reason the figure is naturally higher).

The breakdown of the teachers in our sample with reference to their schools is shown in Table 1 below. The authors think that with the exception of teachers teaching at the university level the teachers were well represented, as the numbers of teachers and their percentages reflect the current situation 
(percentages of students attending classical grammar schools, music and arts secondary school is low compared to students attending other types of school, i.e. the number of teachers teaching in them cannot be high).

Table 1. Characteristics of Teachers According to the Types of School

\begin{tabular}{|l|c|c|}
\hline Type of School & Number of Teachers & Percentage of Teachers \\
\hline Lower grades of primary school & 30 & 11.8 \\
\hline Upper grades of primary school & 125 & 49.0 \\
\hline Vocational secondary schools & 61 & 23.9 \\
\hline Modern FL grammar school & 24 & 9.4 \\
\hline Classical grammar school & 6 & 2.4 \\
\hline General grammar school & 60 & 23.5 \\
\hline Natural science grammar school & 17 & 6.7 \\
\hline Music secondary school & 2 & 0.8 \\
\hline Arts secondary school & 1 & 0.4 \\
\hline University & 8 & 3.1 \\
\hline Other type of institutions & 11 & 4.3 \\
\hline
\end{tabular}

The breakdown of the teachers in our sample with reference to FL(s) they were teaching at the time of data collection is shown in Table 2 below. English is learned by practically all students in the country, followed by German as a much less popular FL, but very often as the only language offered as a second FL by many schools. Italian is popular in the south of the country along the coast. Due to soap operas running on Croatian private and national TV channels, Spanish is getting more and more popular, but there are not many schools where students can take it. Bearing all these facts in mind, it can probably be concluded that the figures and percentages reflect the real situation.

Table 2. Characteristics of Teachers According to Foreign Languages

\begin{tabular}{|l|c|c|}
\hline Foreign language & Number of Teachers & Percentage of Teachers \\
\hline English & 162 & 63.5 \\
\hline German & 112 & 43.9 \\
\hline French & 28 & 11.0 \\
\hline Spanish & 1 & 0.4 \\
\hline Italian & 44 & 17.3 \\
\hline Latin & 4 & 1.6 \\
\hline Other languages & 3 & 1.2 \\
\hline
\end{tabular}

\section{Procedure}

In mid-June 2015 the online questionnaire was uploaded. Data collection was then organised in the second half of June and the beginning of July of the same year. The authors of the paper sent an invitation e-mail to FL teacher representatives in all the 20 Croatian counties asking them to forward it to as many FLTs in private and secondary schools as possible. The invitation e-mail acquainted the teachers with the purpose of the study, gave them an Internet 
link to the online questionnaire (http://goo.gl/forms/3XfTO6DNCp), informed them that their participation was voluntary and asked them kindly to fill it in. Knowing that nowadays teachers can be piled with many similar invitations, they hoped to get a three-digit figure of teacher response.

\section{Results}

Bearing in mind the starting hypothesis and taking into the consideration the aims of the study, the analysis of the results was subdivided into six subsections. The first one deals with FL teachers ICT equipment at home and at their place of work, the second one with teachers' daily ICT practices, the third one with the self-assessments of their own competences; the fourth subsection analyzes the relationshp between teachers' time spent on the computer and the Internet and their assessments of their ICT competences; the fifth subsection is a presentation of the FLT's experience with ICT equipment and sofware in FL teaching; the last subsection is a review of teachers' comments.

\section{How well are FL Teachers Equipped with ICT Technology at Home and at their Schools or Institutions of Higher Education?}

As for the ICT computer data, here is the summary of the main characteristics of the teachers in the sample. $99 \%$ of them possess a PC at home and $83.9 \%$ at their place of work. A considerable number of teachers have to share the computer with other people in their household. The answers varied from one to four other members. The situation is worse at school. It is most common for teachers to share a computer with other teachers in the same institution. 30 was the highest number mentioned. Very dissatisfying is the fact that only $45.1 \%$ of the teachers teach FLs in classrooms equipped with a computer, and only $37 \%$ with a projector.

Computers become a more valuable tool, if they are connected to the Internet. It is good to know that all the teachers equipped with computers at home have access to the Internet. $95.3 \%$ of their schools are connected to the Internet. About $90 \%$ of the teachers have rated the quality of their Internet connection at home with grades 4 or 5, but they are much less satisfied with the quality of their Internet connections in their institutions. The dominant grade was 3 and about one third of the teachers in the sample have rated it with the average grade. About $15 \%$ have rated it with lower grades 1 and 2 . About one half of them are very satisfied and have rated their school Internet connections with grades 4 and 5. More than a half of the classrooms where FLs are taught in the schools in the survey do not have access to the Internet.

$23.1 \%$ of the teachers in the survey have never had any formal instruction in ICT and $59.6 \%$ of them have had some formal instruction in the use of ICT in teaching FLs. In $78 \%$ of the schools ICT administrators are available. It is positive that more than one half of the teachers have rated their support with 
grades 4 and 5. Only $15 \%$ are unsatisfied and the rest of the teachers regard their support as neither too good nor too bad.

It can be concluded that considering the overall financial situation in Croatia, Croatian FL teachers invest a great deal in their ICT technology at home, but that there is a great demand for improvement in ICT technology in schools and especially in classrooms where FLs are taught. It is also not acceptable that educational institutions in a country belonging to EU are without ICT administrators.

\section{FL Teachers' Daily ICT Practices}

The analysis of time spent on the computer (see Figure 1) has shown that about four fifths of the teachers in the sample spend less than three hours on their computer. A comparison of the lengths of bars in Figure 1 and 2 reveals that the difference between the total time spent on the computer and the time spent on computers for school purposes is not very different. This would mean that FL teachers in the sample use their computers primarily for school purposes. According to our analysis, teachers in the sample spend 1.87 hours on average on their computers for their school work. All these figures suggest that Croatian FL teachers are prone to use ICT technology.

Figure 1. Daily Average Amount of Time Spent on the Computer

$$
80
$$

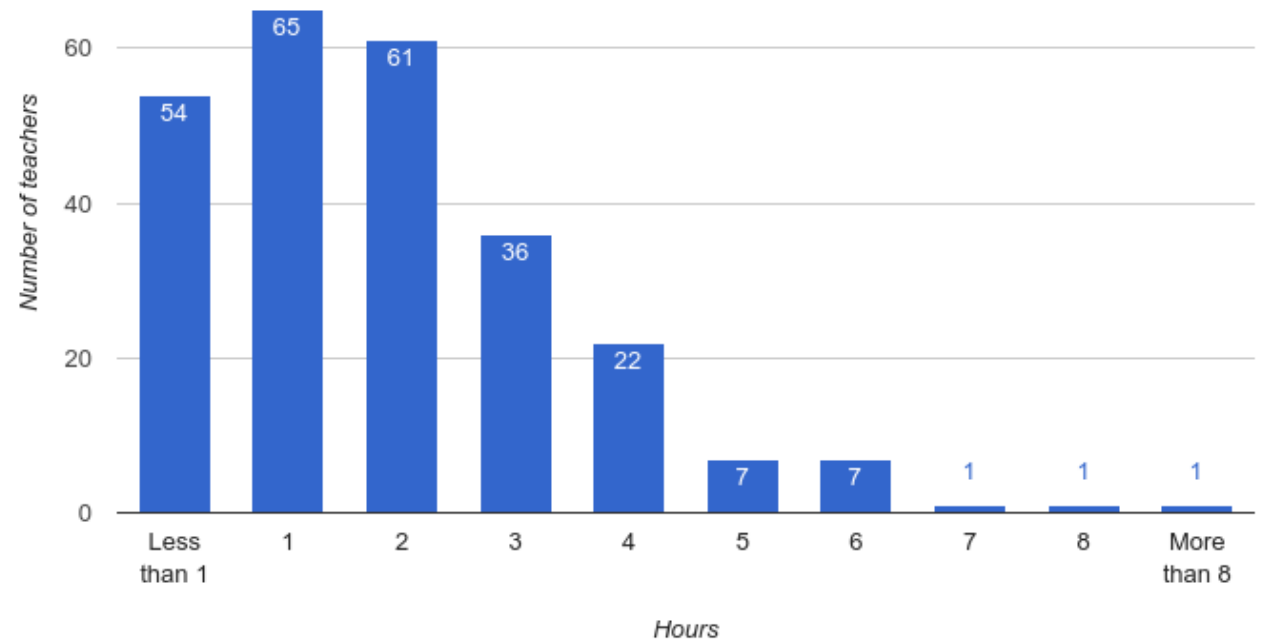

The analysis of the length of bars in Figure 3 reveals that the Internet is a very important source of information for FL teachers in Croatia. The comparison with lengths of bars in Figures 1 and 2 shows that Croatian FLTs stay online most of the time when they work on computers both either for leisure or for their school purposes. 
Figure 2. Daily Average Amount of Time Spent on the Computer for School Purposes

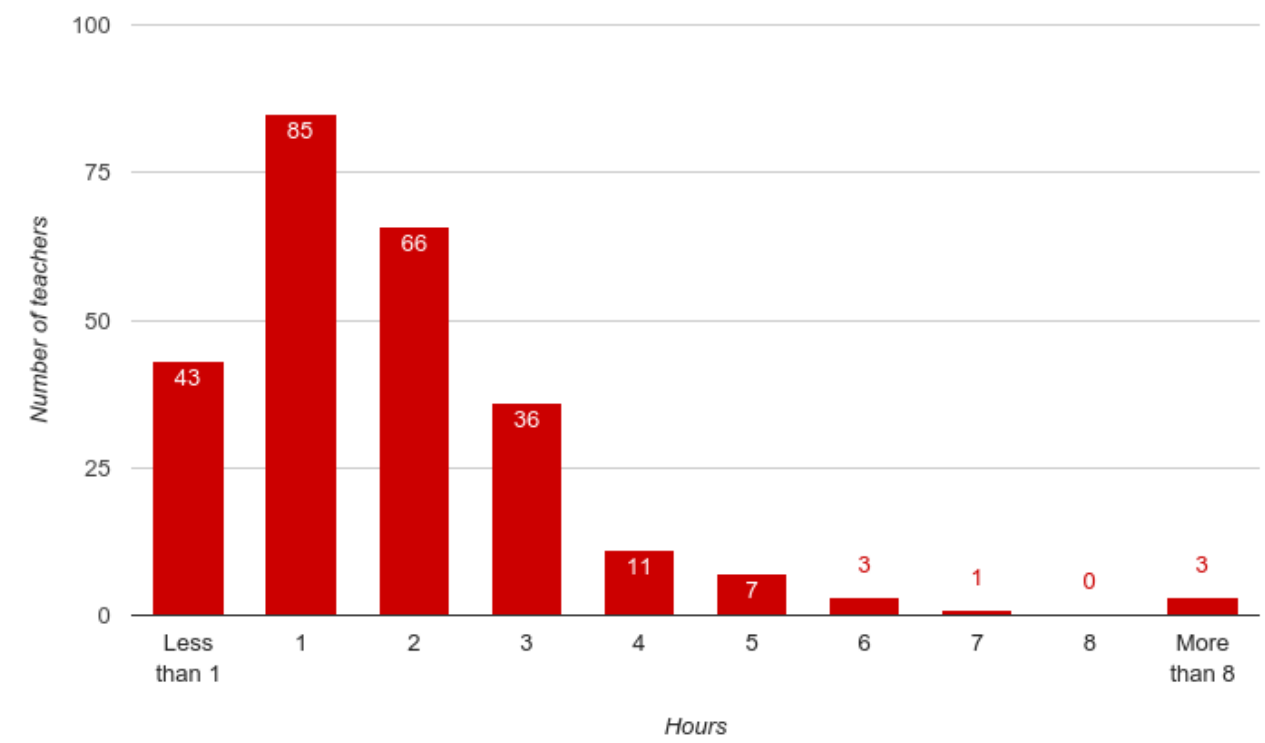

Figure 3. Daily Average Amount of Time Spent on the Internet

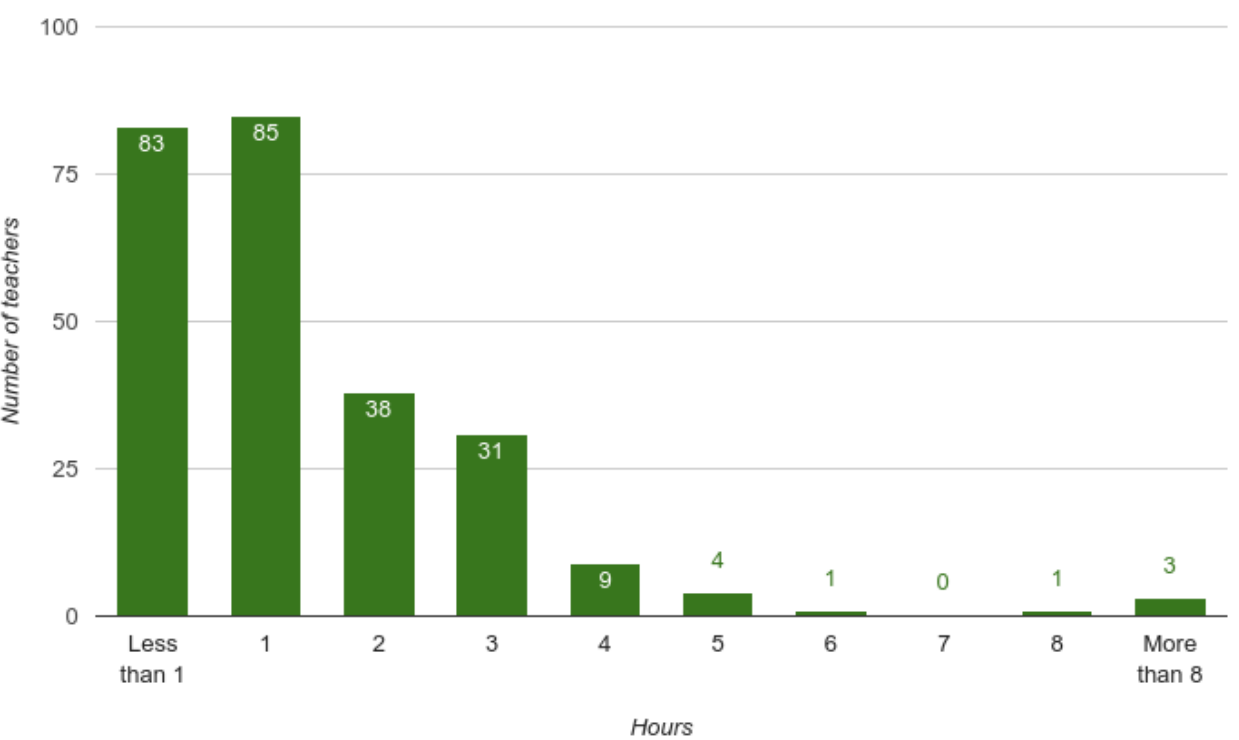

\section{Analysis of FLTs' Self-assessments of their own competences}

Items from the questionnaire dealing with teachers' self-assessments of competences were targeting teachers' general ICT competences and their special ICT competences for FL teaching.

General ICT competences. Six general ICT competencies were included in the questionnaire. The analyses of the results of all the six analysed 
competences presented in the six graphic charts (see Figures 4-9) show that the highest number of FLT who regard their competence as very good or excellent can be found in Figures 5 and 7. The surveyed teachers gave most high grades to describe their ICT competence to seek information and to work with and distribute information (searching the web, creating folders...) and their ICT competence to present information (PowerPoint). 105 of 255 teachers have given the best possible grade 5 to describe their ability to search the web and create a folder, and 88 of them the grade 4 . The mean value for this item was highest. It was 4.12. Next in line when measured by the number of satisfied teachers comes the competence for presenting information. This fact tells us that PowerPoint seems to be a very common tool used by many teachers to present new language materials and that they have mastered it well. 95 of 255 teachers in the sample have given the best possible grade 5 to describe their competence in using computers to present information. It was followed by grade 4, which was given by 89 teachers in the sample. However, the highest number of unsatisfied teachers can be found in the same chart. Eight teachers regarded their competence to present information via computer completely unsatisfactory and 25 think that it is very poor. The mean for this value was 3.93.

From the length of bars in Figures 4 and 6 it seems that Croatian FLT think that they are more competent in using computers to arrange documents than to use them to create new information and to create and share information. To get a better comparison, the mean values were calculated. For the selfassessment in Figure 4 it was 3.95. It is interesting to note that the mean value is equal in the self-assessments presented in Charts 5 and 6, and it was 3.68. Therefore, it can be concluded that according to the self-assessment of Croatian FLTs, they really have a higher competence in arranging documents on computers than in using computers collect and create information or to exchange and create information. Furthermore, it was also found that due to teachers who cannot use PowerPoint and similar programs, the competence of the teachers in the sample in using computers for presenting information was even regarded to be lower $(M=3.93)$ than their competence in using computers for arranging documents $(\mathrm{M}=3.95)$.

The mean values of the competences presented in Charts 8 and 9 suggest that the surveyed Croatian FL teachers are least satisfied with their competence to use computers to create new teaching materials $(\mathrm{M}=3.25)$ and with their competence to monitor students' progress $(\mathrm{M}=3.22)$. The length of the bars reveal an even higher dissatisfaction because of the inability to monitor students' progress because as many as 30 teachers $(11.8 \%)$ have given themselves grade 1 and $40(15.7 \%)$ grade 2 in this item.

From all this the authors can conclude that general ICT competences are mediocre and that they need some improvements. Most teachers need assistance that would help them improve their competences to create teaching materials (Moodle and similar ones) and to monitor the progress of their students. 
Figure 4. Teachers' Self-Assessment of Their Own Competence in Using Computers for Arranging Documents (Word, Excel)

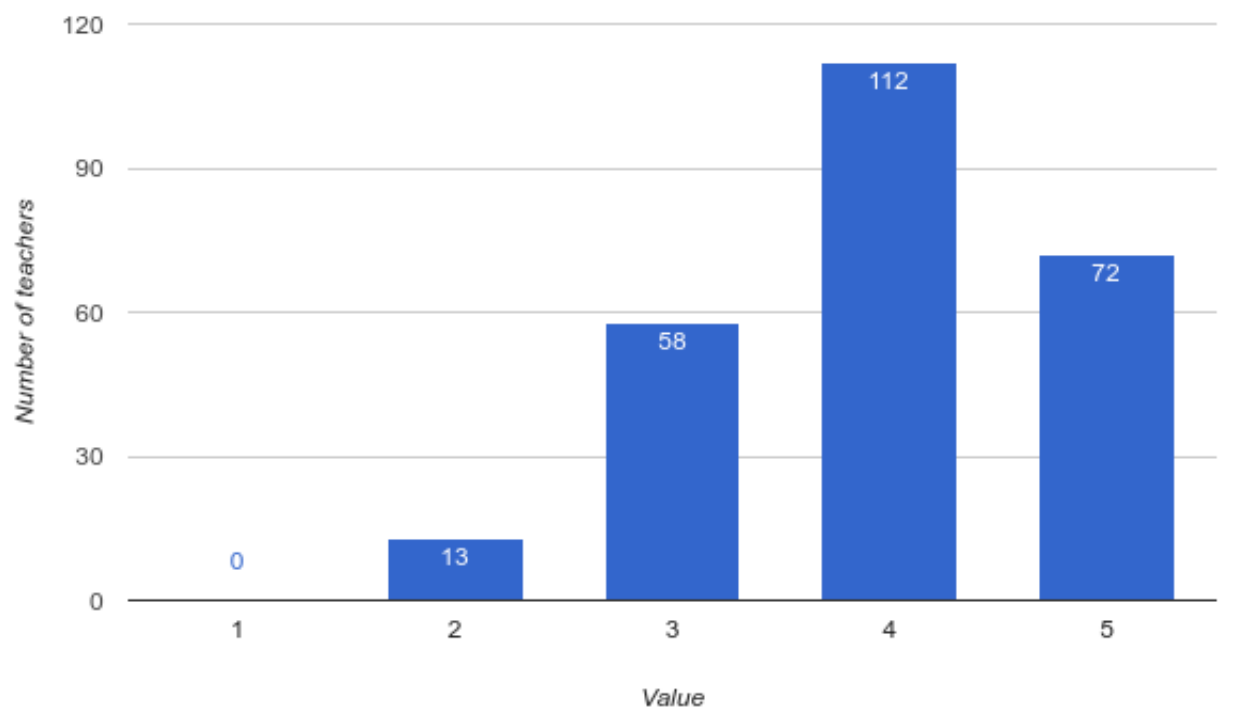

Figure 5. Teachers' Self-Assessment of Their Own Competence in Using Computers for Seeking Information Working with Information and Distributing Information (Searching the Web, Creating Folders...)

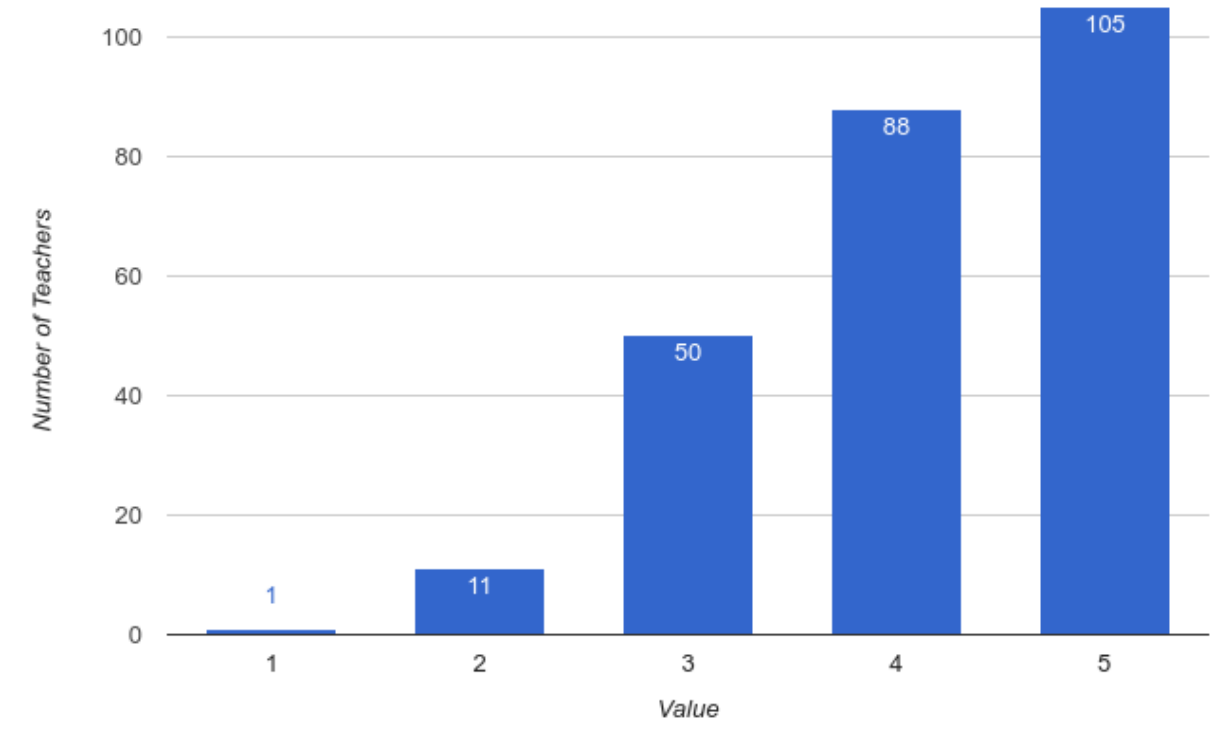


Figure 6. Teachers' Self-assessment of their Own Competence in Using Computers for Creation and Exchange of Information (E-mail, Chat, Creation of Personal Webpage)

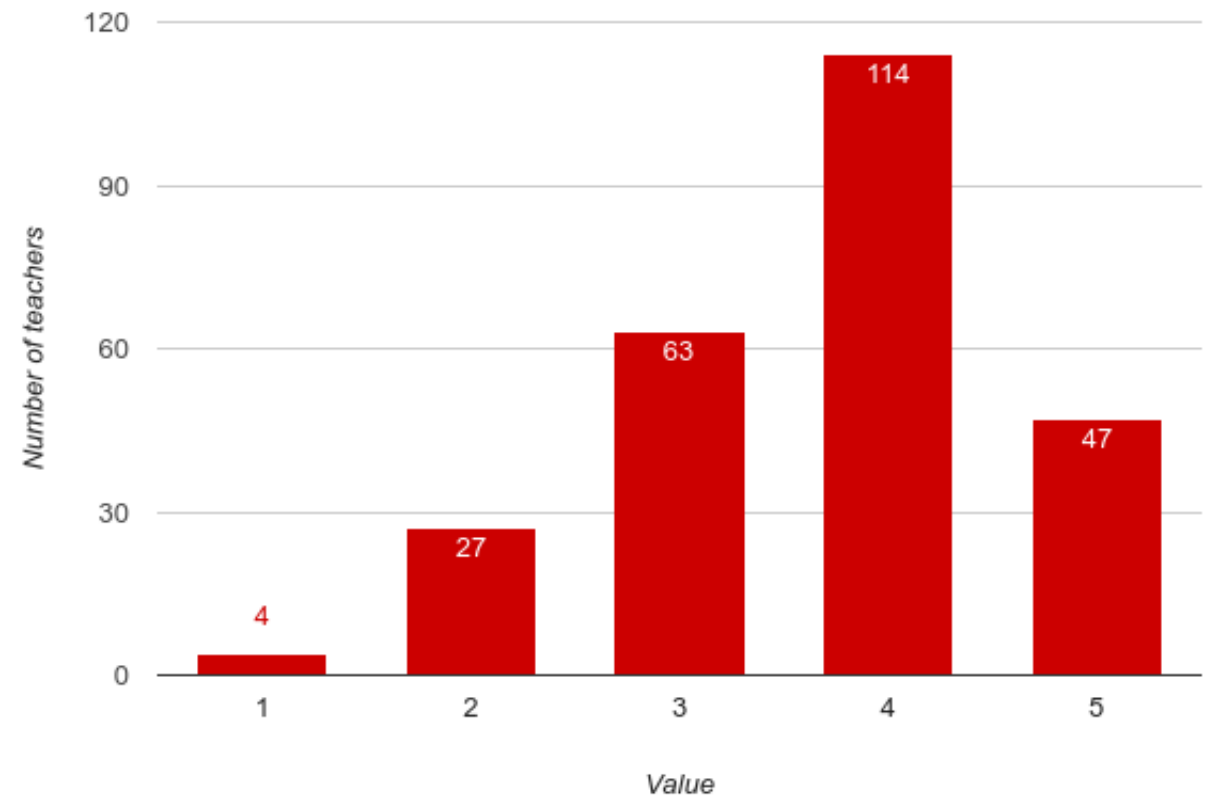

Figure 7. Teachers' Self-assessment of their own Competence in Using Computers to Present Information (PowerPoint)

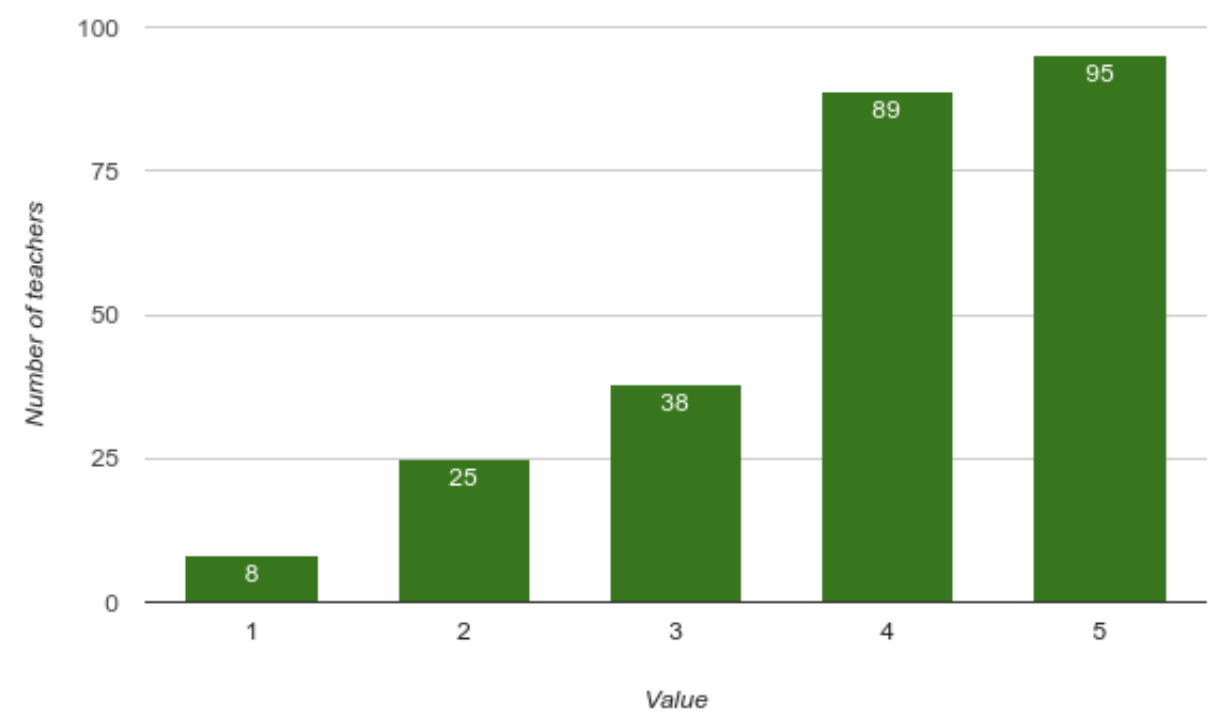


Figure 8. Teachers' Self-assessment of their own Competence in Using Computers for Creation of Teaching Materials (Moodle and similar ones)

$$
100
$$

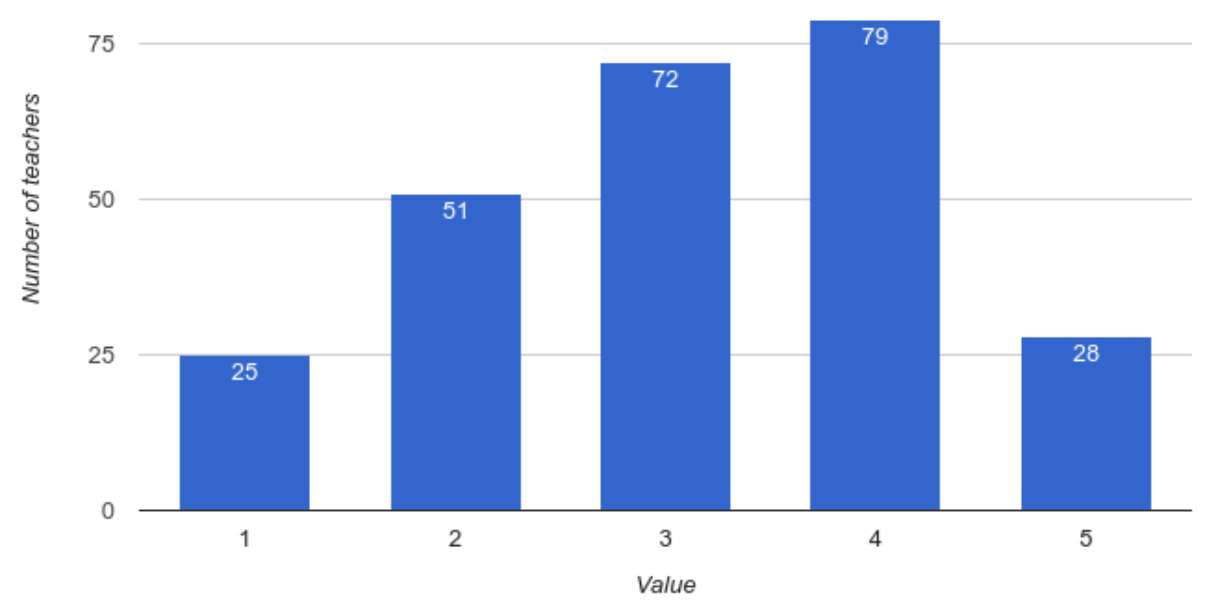

Figure 9. Teachers' Self-assessment of their own Competence in Using Computers for Monitoring Students' Progress

$$
100
$$

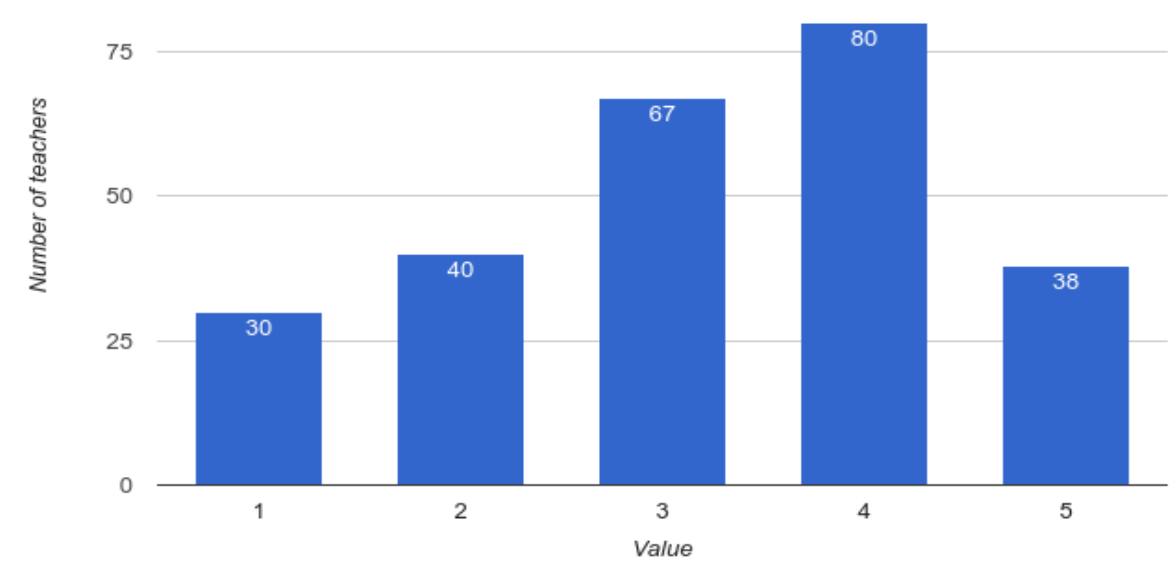

Special ICT competences for FL teaching. The calculations of the mean values for all six special ICT competences for FL teaching that were included in the questionnaire yielded the following results: competence in using ICT for creation of authentic FL environment - M=3.27, competence in using computers for the creation of multifunctional exercises and tests $-\mathrm{M}=3.12$, competence in using the FL education software $-\mathrm{M}=3.08$, competence in using ICT for adoption of correct pronunciation - M=3.08, competence in using computer games for FL learning - M=2.95 and competence in using computer software for distance and e-learning - M=2.57 (see Figures 10 to 15). All these values are lower than the mean values that were calculated for general ICT 
competences. All this suggests that Croatian FL teachers should be assisted in acquiring a higher competence in using computers to teach FLs. Attention of Croatian FL teachers should be pointed to high potentials of using computers for distance and e-learning which could all help their FL students to benefit from ICT technology.

Figure 10. Teachers' Self-assessment of their Own Competence in Using the FL Education Software

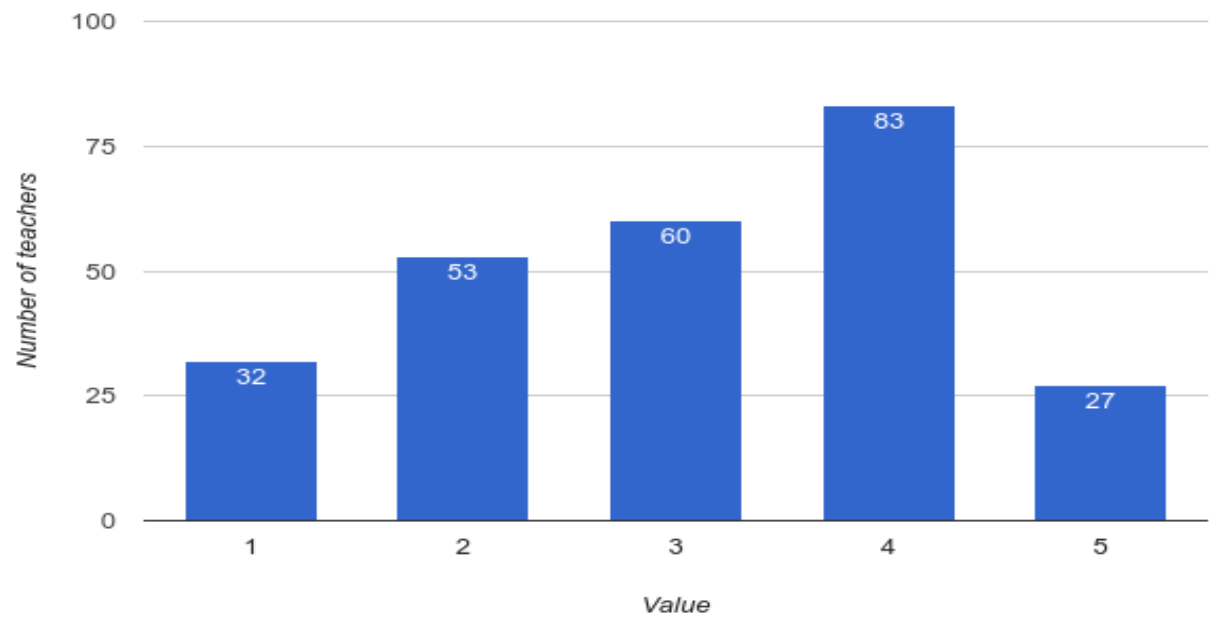

Figure 11. Teachers' Self-assessment of their Own Competence in Using Computers for Creation of Multifunctional Exercises and Tests

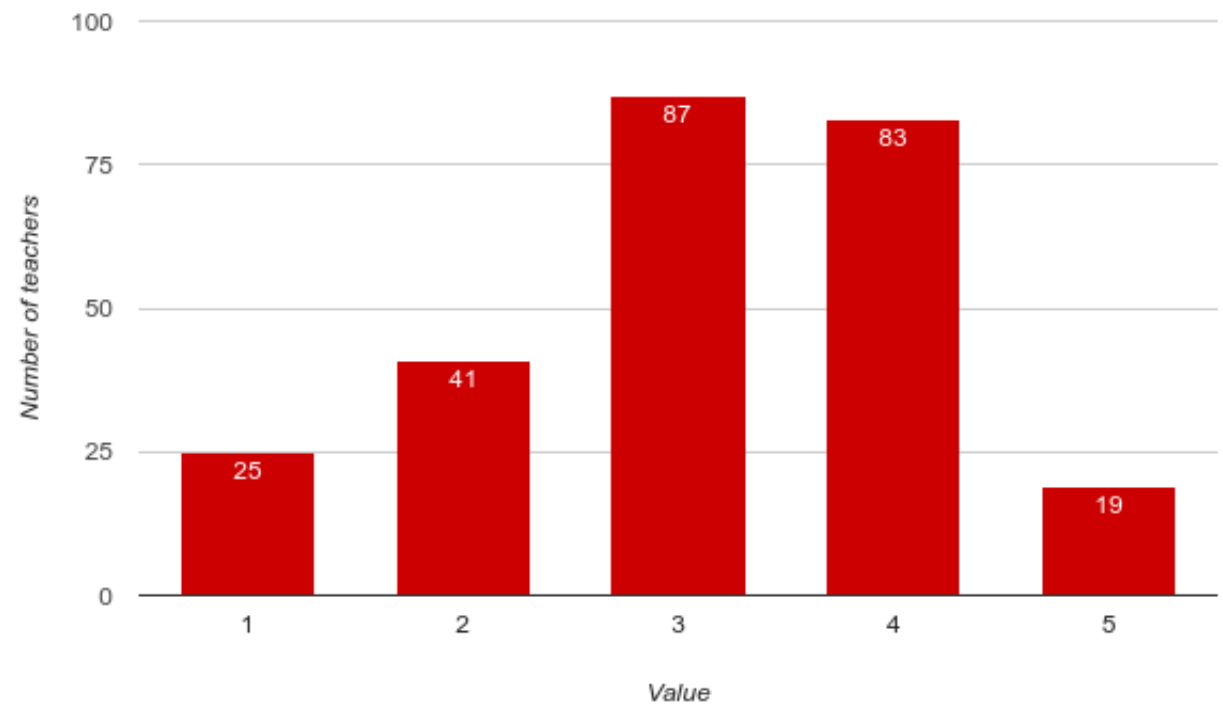


Figure 12. Teachers' Self-assessment of their Own Competence in Using Computer Software for Distance and E-learning

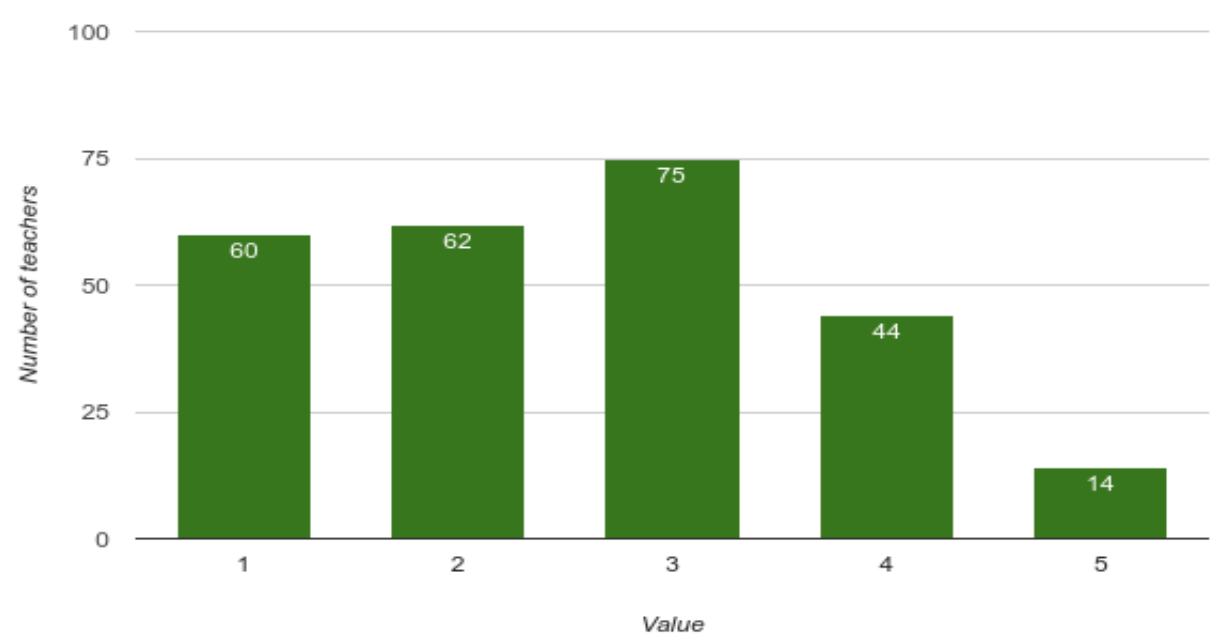

Figure 13. Teachers' Self-assessment of their Own Competence in Using ICT for Creation of Authentic FL Environment

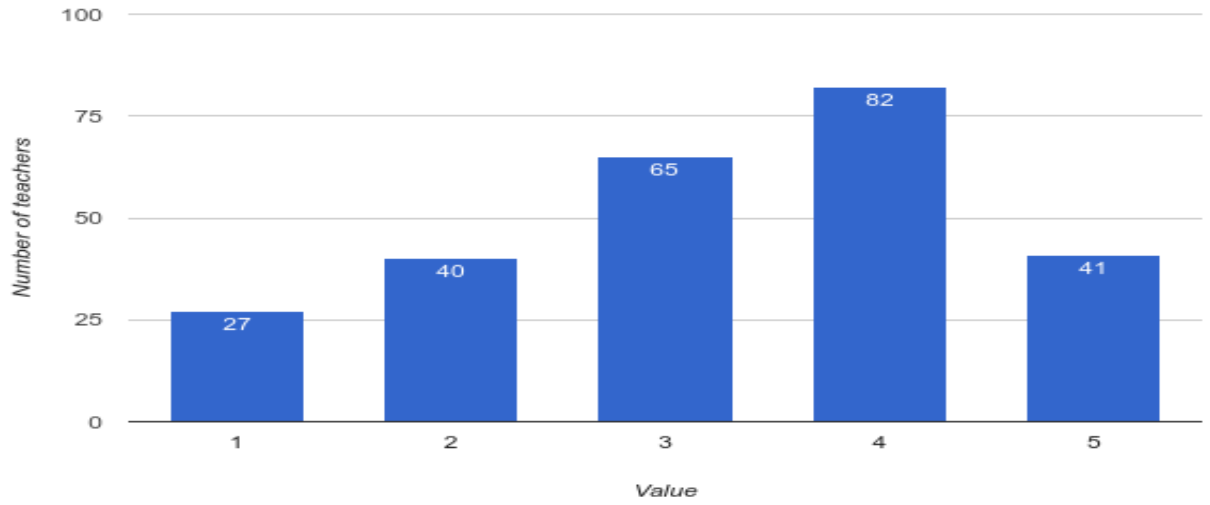

Figure 14. Teachers' Self-assessment of their own Competence in Using ICT for Adoption of Correct Pronunciation

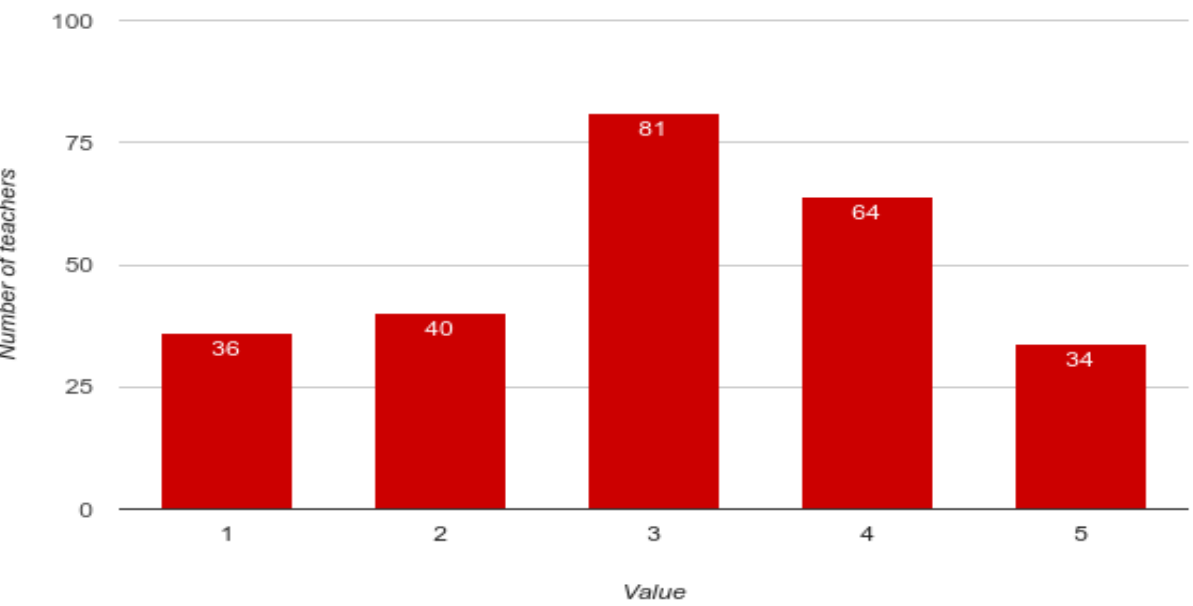


Figure 15. Teachers' Self-assessment of their own Competence in Using Computer Games FL Learning

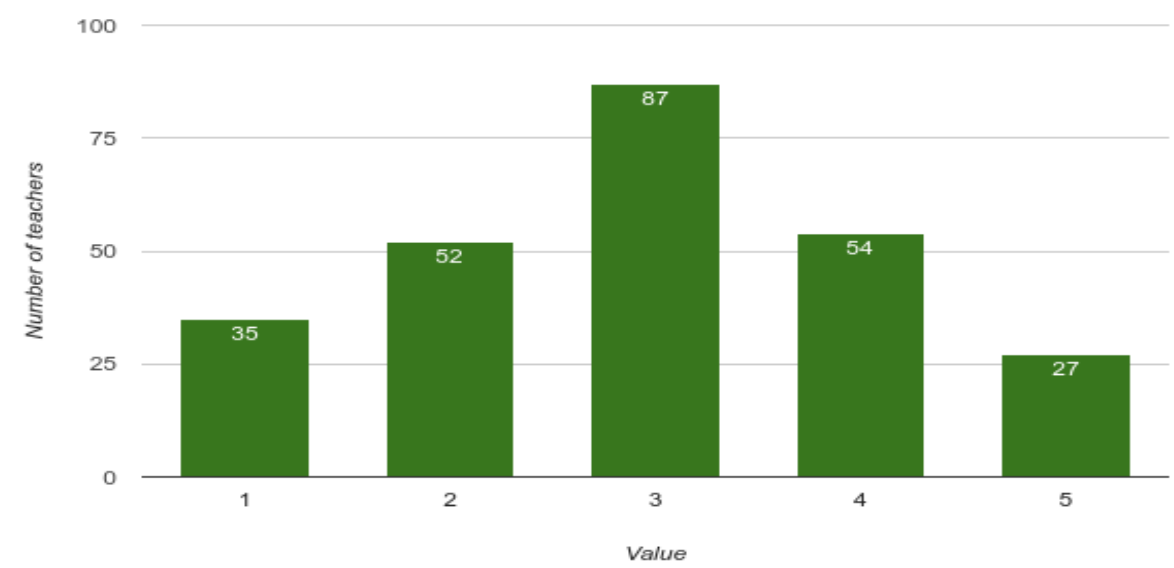

Relationship between Teachers' Time Spent on the Computer and Internet and their Assessments of their ICT Competences

In order to get an insight into the relationship between the teachers' time spent on the Internet and their assessments of their ICT competences, correlation coefficients were calculated. A quick glance at the correlation coefficients in Table 3 reveals that all the correlations are positive and statistically significant with one exception (the correlation between teachers' self-assessment of their own competence in using ICT for adoption of correct pronunciation and the time spent on the Internet, which is positive, but not statistically significant). It can also be seen that none of the correlations are too strong. The strongest correlation $(r=.353)$ is the correlation between the selfassessed competence in using computers for creation and exchange of information and the time spent on the computer. The weakest of the statistically significant correlations is the correlation between competence in using the FL education software and the time spent on the Internet $(r=.130)$. Most correlations are significant at the 0.01 level, and a smaller number at the 0.05 level. From this it can be concluded that the authors' starting hypothesis has been confirmed. In other words, the increase of the time spent on computers and the Internet by FLT in Croatia leads to the increase in their ICT competences. 
Table 3. Correlation Coefficients between Time Spent on the Computer and Teachers' Self-assessments of their ICT Competences

\begin{tabular}{|c|c|c|c|}
\hline $\begin{array}{l}\text { Teachers' Self-Assessments of } \\
\text { Their Own Competences }\end{array}$ & $\begin{array}{l}\text { Time Spent } \\
\text { on the } \\
\text { Computer }\end{array}$ & $\begin{array}{l}\text { Time Spent on } \\
\text { the Computer } \\
\text { for School } \\
\text { Purposes } \\
\end{array}$ & $\begin{array}{c}\text { Time Spent } \\
\text { on the } \\
\text { Internet }\end{array}$ \\
\hline $\begin{array}{l}\text { Competence in using computers } \\
\text { for arranging documents (Word, } \\
\text { Excel) }\end{array}$ & $.282^{* *}$ & $.206^{* *}$ & $.204 * *$ \\
\hline $\begin{array}{l}\text { Competence in using computers } \\
\text { to create and exchange } \\
\text { information (e-mail, chat, } \\
\text { creating personal web-pages) }\end{array}$ & $.305^{* *}$ & $.202 * *$ & $.254 * *$ \\
\hline $\begin{array}{l}\text { Competence in using computers } \\
\text { for creation and exchange of } \\
\text { information (e-mail, chat, } \\
\text { creation of personal webpage) }\end{array}$ & $.353 * *$ & $.207 * *$ & $.308 * *$ \\
\hline $\begin{array}{l}\text { Competence in using computers } \\
\text { to present information } \\
\text { (PowerPoint) }\end{array}$ & $.226^{* *}$ & $.232 * *$ & $.168 *$ \\
\hline $\begin{array}{l}\text { Competence in using computers } \\
\text { to create teaching materials } \\
\text { (Moodle and similar ones) }\end{array}$ & $.260 * *$ & $.216^{* *}$ & $.158 *$ \\
\hline $\begin{array}{l}\text { Competence in using computers } \\
\text { to monitor students' progress }\end{array}$ & $.233 * *$ & $.214 * *$ & $.189 * *$ \\
\hline $\begin{array}{l}\text { Competence in using the foreign } \\
\text { language education software }\end{array}$ & $.155^{*}$ & $.200 * *$ & $.130 *$ \\
\hline $\begin{array}{l}\text { Competence in using computers } \\
\text { for creation of multifunctional } \\
\text { exercises and tests }\end{array}$ & $.196^{* *}$ & $.194^{* *}$ & $.185^{* *}$ \\
\hline $\begin{array}{l}\text { Competence in using computer } \\
\text { software for distance and e- } \\
\text { learning }\end{array}$ & $.189 * *$ & $.184 * *$ & $.173 * *$ \\
\hline $\begin{array}{l}\text { Competence in using ICT for } \\
\text { creation of authentic foreign } \\
\text { language environment }\end{array}$ & $.214 * *$ & $.313^{* *}$ & $.158 *$ \\
\hline $\begin{array}{l}\text { Competence in using ICT for } \\
\text { adoption of correct pronunciation }\end{array}$ & $.130 *$ & $.222 * *$ & .102 \\
\hline $\begin{array}{l}\text { Competence in using computer } \\
\text { games for foreign language } \\
\text { learning }\end{array}$ & $.228 * *$ & $.148 *$ & .200 \\
\hline
\end{tabular}

*Correlation is significant at the 0.05 level

** Correlation is significant at the 0.01 level

\section{Teachers' Experience with ICT Equipment and Software in FL Teaching}

Ten items belonging to the last section of the questionnaire asked FL teachers to assess their experience with ICT equipment and software in their work. Mean values had to be calculated and it can be seen from Table 4 below 
that all of them are above value 3 , which means that Croatian teachers are more satisfied than unsatisfied in their assessment of their experience with ICT equipment in teaching FL to their students. They are least satisfied with efficiency of feedback for students $(\mathrm{M}=3.06)$ and their classroom management when using ICT equipment and software while teaching $(\mathrm{M}=3.07)$. More than one quarter of the teachers in the sample have given grades one or two as their answers for these two items. This could lead us to the conclusion that many Croatian FL teachers tend to think that efficient feedback for their students is only possible if they can hear their teachers' oral confirmation that their answer is correct or see written grades in school register books as well as that they might fear that they could lose control of their classroom work if some new technology is introduced into the classroom.

Very close results have been obtained for the following four items: the increase in students' usage of FL structures $(M=3.31)$, the increase of students' self-confidence in FL $(M=3.33)$, the improvement of students' pronunciation $(\mathrm{M}=3.34)$, the increase in students' desire for real communication with interlocutors in FL $(M=3.35)$. The distribution of teachers' grades for their assessments in these items shows that close to half of the teachers have given grades four or five in three of these items and $51 \%$ in the item about the improvement of students' pronunciation. These results tell us that Croatian FL teachers assume that their students have benefited from the use of ICT technology on various fields: students can use more FL structures, their selfconfidence can be raised, their pronunciation can be improved and they are more interested in real communication with interlocutors in FL.

Mean value calculations have yielded even higher and again very similar results for the following three items: the lowering of students' language anxiety $(M=3.41)$, acquisition of FL vocabulary $(M=3.43)$ and the improvement of students' knowledge when ICT equipment and software are used $(\mathrm{M}=3.45)$. FL anxiety can be a serious debilitating factor in FL learning and any positive steps which lead to its lowering can only be positively greeted. The ranking of this item in the final hierarchy was pretty high. Furthermore, it is also good to know that teachers think that through the use of ICT equipment students can increase their FL word power and knowledge. More than a half of teachers have given grades 4 and 5 in all these three items.

The teachers in the sample were mostly satisfied with ICT equipment when they had to assess the increase in students' desire to learn FLs and their curiosity about FLs. The mean value for this item was the highest $(M=3.62)$. Close to two thirds of the teachers in the sample have rated their experience in this item with grades four and five, and only a little more than $13 \%$ have given poor grades one and two. This result alone would be a reason enough to justify the use of ICT equipment in FL teaching.

To sum up, we can say that Croatian FLT have had pretty good experience with their use of ICT technology, but they should be helped to learn more about class management and about the efficiency of the students' feedback when ICT equipment and software are used in FL teaching. 
Table 4. Teachers' assessments of their experience with ICT equipment in FL teaching equipment in FL teaching

\begin{tabular}{|c|c|c|c|c|c|c|}
\hline \multirow{3}{*}{$\begin{array}{l}\text { Various kinds of } \\
\text { teachers' } \\
\text { experience }\end{array}$} & \multicolumn{5}{|c|}{$\begin{array}{c}\text { Teachers' answers according to a 5-point Likert } \\
\text { scale (in percentages) }\end{array}$} & \multirow{3}{*}{$\begin{array}{l}\text { Mean } \\
\text { value }\end{array}$} \\
\hline & \multicolumn{5}{|c|}{ Values } & \\
\hline & 1 & 2 & 3 & 4 & 5 & \\
\hline $\begin{array}{l}\text { Classroom } \\
\text { management }\end{array}$ & 13.7 & 13.3 & 34.1 & 29.4 & 9.4 & 3.07 \\
\hline $\begin{array}{l}\text { Efficiency of } \\
\text { feedback for } \\
\text { students }\end{array}$ & 16.1 & 10.2 & 34.9 & 29 & 9.8 & 3.06 \\
\hline $\begin{array}{l}\text { Increase of } \\
\text { students' self- } \\
\text { confidence in FL }\end{array}$ & 10.6 & 9 & 32.3 & 33.3 & 14.9 & 3.33 \\
\hline $\begin{array}{l}\text { Lowering of } \\
\text { students' language } \\
\text { anxiety }\end{array}$ & 9.8 & 8.6 & 29 & 36.1 & 16.5 & 3.41 \\
\hline $\begin{array}{l}\text { Increase in } \\
\text { students' desire to } \\
\text { learn FLs }\end{array}$ & 8.2 & 5.1 & 23.5 & 37.6 & 25.5 & 3.67 \\
\hline $\begin{array}{l}\text { Increase in } \\
\text { students' desire for } \\
\text { real communication }\end{array}$ & 8.6 & 7.8 & 35.3 & 36.1 & 12.2 & 3.35 \\
\hline $\begin{array}{l}\text { Acquisition of FL } \\
\text { vocabulary }\end{array}$ & 7.8 & 9.4 & 31.4 & 34.9 & 16.5 & 3.43 \\
\hline $\begin{array}{l}\text { Increase in } \\
\text { students' usage of } \\
\text { FL structures } \\
\end{array}$ & 9 & 9.4 & 32.5 & 40 & 9 & 3.31 \\
\hline $\begin{array}{l}\text { Improvement of } \\
\text { students' } \\
\text { pronunciation }\end{array}$ & 9 & 10.2 & 29.8 & 40 & 11 & 3.34 \\
\hline $\begin{array}{l}\text { Improvement of } \\
\text { students' } \\
\text { knowledge }\end{array}$ & 7.5 & 9.8 & 27.5 & 40.8 & 14.5 & 3.45 \\
\hline
\end{tabular}

\section{Teachers Comments}

Although they were invited to leave their own comments to the authors of the survey, none of the surveyed teachers felt the need for it, i.e. none of them took advantage of this opportunity. It should also be noted that no comments were received by e-mail either. The invitation e-mail that had been sent to FLT contained e-mail addresses of all three authors. Only a few messages were received from one county coordinator and several other teachers who needed further instructions to access the online survey. They did not know what to do with the link. This problem was solved on the same day. 


\section{Conclusion}

The results of this study have shown that Croatian FLT's ICT equipment at home is satisfactory, whereas there exists a considerable demand for its improvement in FL classrooms and schools. They are prone to use ICT technology. On average they spend 1.87 hours daily on a computer and the Internet working for school purposes. Their general ICT competences are mediocre and ask for improvements. It is also apparent that they should be assisted in acquiring a higher competence in using computers to teach FLs and that they do not use the high potentials offered by computers for distance and e-learning enough. Their increase in time spent on computers and the Internet is accompanied by an increase in their ICT competences. Items dealing with teachers' experience with ICT equipment in FL tuition have shown tendency towards their positive experience.

\section{Acknowledgments}

Our thanks goes to all the teachers who responded to our invitation and filled in our online questionnaire as well as to all FL county representatives who helped us get in touch with teachers and thus enabled us to get a valuable insight into ICT competences and practices of FLT in Croatia.

\section{References}

Brigas, C. (2016). Use of ICT in school context: Pupils, parents' and teachers perceptions. In M. J. Marcellino et al. (Eds.), ICT in Education: Multiple and Inclusive Perspectives (pp. 97-114). Cham: Springer.

Cajkler, W., \& Addelman, R. (2012). The practice of foreign language teaching. New York/London: Routledge

Cartelli, A. (2012). Teaching in the knowledge society: between technology and competences. In A. Jimoyiannis (Ed.), Research on e-Learning and ICT in Education (pp. 43-54). New York: Springer.

Engler, T., \& Mikulan, K. (2006). Synergetische potentiale des multimedialen fremdsprachenunterrixchts [Synegetic potentials of multimedia foreign language teaching]. Neos 1(1), 31-47.

Green Paper on Teacher Education. (2000). TNTEE. Retrieved from http://bit.ly/2cn $0 \mathrm{~A} 5 \mathrm{Z}$.

Gretter, S., \& Gondra, A. (2016). Teaching foreign languages in the twenty-first century: lessons from spanish hybrid education. In C.-H., Lin, et al. (Eds.), Preparing Foreign Language Teachers for Next-Generation Education (pp. 92113). Hershey: IGI Global.

Grosbois, M. M., \& Sarré, C. G. (2016). Learning to teach for next-generation education: a careful blend of action and reflection. In C.-H. Lin, et al. (Eds.), Preparing Foreign Language Teachers for Next-Generation Education (pp. 153174). Hershey: IGI Global.

Halvorsen, A. D. (2016). Divergent Teacher viewpoints of technology integration in 
the language classroom. In C.-H. Lin, et al. (Eds.), Preparing Foreign Language Teachers for Next-Generation Education (pp. 130-152). Hershey: IGI Global.

Henry, M. (2014). Learning in the digital age: developing critical, creative and collaborative skills. In S., Younie, et. al. (Eds.), Teaching and Learning with ICT in the Primary School (Ch. 1). New York/London: Routledge.

Johansson, P. \& Gardenfors, P. (2012). Introduction to cognition, education, and communication technology. In P. Gardenfors, \& P. Johansson (Eds.), Cognition, Education, and Communication Technology (pp. 1-21). New York/London: Routledge.

Kozma, R. B. (2011). Transforming education: the power of ICT policies. Paris: UNESCO

Laurillard, D. (2012). Teaching as a design science: building pedagogical patterns for learning and technology. New York: Routledge.

Legac, V., \& Mikulan, K. (2003). Uloga racunala u ranom ucenju stranoga jezika [The role of teachers in teaching foreign languages to young learners] In I. Vodopija (Ed.) Dijete i jezik danas; Ucitelj hrvatskoga jezika i ucitelj stranoga jezika za ucenike mlade skolske dobi [Child and Language Today; Teacher of Croatian and Teacher of Foreign Languages in Lower Grades of Primary School] (pp. 154167). Osijek: Sveuciliste Josipa Jurja Strossmayera.

Li, L., \& Walsh, S. (2011). "Seeing Is Believing": Looking at EFL Teachers' Beliefs through Classroom Interaction. Classroom Discourse, 2(1), 39-57.

Light, D., \& Pierson, E. (2014). Case studies of Russian educators transforming classroom practices through ICT-rich school environments. In R., Huang, et al. (Eds.), ICT in Education in Global Context: Emerging Trends Report 2013-2014, 47-65. Berlin-Heidelberg: Springer.

Liu, H., Lin, C.-H., Zhang, D., \& Zheng, B. (2016). Language teachers' perceptions of external and internal factors in their instructional (non-) use of technology. In CH., Lin, et al. (Eds.), Preparing Foreign Language Teachers for Next-Generation Education (pp. 56-73). Hershey: IGI Global.

Mihaljevic Djigunovic, J. (2008). Education of foreign language teachers in Croatia. In N. Pintaric (Ed.), Tuning teacher education curricula in the Western Balkans (pp. 86-96). Beograd: Centre for Education Policy.

Mihaljevic Djigunovic, J., \& Mardesic, S. (2009. Kompetencije nastavnika stranih jezika izmedu politike i stvarnosti [Foreign language teachers' competences between politics and reality]. In J. Granic (Ed.), Language Policy and Language Reality (pp. 319-327). Zagreb and Osijek: HDPL.

Mikulan, K. (2008). Multimedia competences of primary foreign language teachers. In H. Sarter (Ed.), Teacher Competences and Successful Learning in Early foreign Language Classrooms (pp. 137-146). Aachen: Shaker Verlag.

Price, S. (2013). Tangibles: Technologies and interaction for learning. In S. Price, et al. (Eds.), The SAGE Handbook of Digital Technology Research (Ch. 20). Los Angeles/London: SAGE

Radisic, M., Pavicic Takac, V., \& Bagaric, V. (Eds.). (2007). Competences of primary school foreign language teachers in the Republic of Croatia, Osijek: University in Osijek and Faculty of Teacher Education in Osijek.

Scaife, M., \& Rogers, Y. (2012). External cognition, innovative technologies, and effective learning. In Gardenfors, \& P. Johansson, (Eds.), Cognition, Education, and P.Communication Technology (pp. 181-202). New York/London: Routledge.

Selwyn, N. (2012). School 2.0: Rethinking the future of school in the digital age. In A. Jimoyiannis, (Ed.), Research on e-Learning and ICT in Education (pp. 3-16). New York: Springer. 
Underwood, J. (2014). Digital technologies: An effective educational change agent? In C., Karagiannidis, et al. (Eds.), Research on e-Learning and ICT in Education: Technological, Pedagogical and Instructional Perspectives (pp. 3-14). New York: Springer.

Vasbo, K. B., \& Gudmundsdottir, G. B. (2014). Methodological challenges when exploring new learning sites in educational research. In G. B. Gudmundsdottir \& K. B. Vasbo (Eds.), Methodolodical Challenges When Exploring Digital Learning Spaces in Education (pp. 1-12). Rotterdam: Sense.

Vekiri, I. (2014). Teacher preparation for educational technology. In C. Karagiannidis, et al. (Eds.), Research on e-Learning and ICT in Education: Technological, Pedagogical and Instructional Perspectives (pp. 245-264). New York: Springer.

$\mathrm{Wu}$, D. (2014). An introduction to ICT in education in China. In R.Huang, et al. (Eds.), ICT in Education in Global Context: Emerging Trends Report 2013-2014 (pp. 65-84). Berlin-Heidelberg: Springer.

Yonemoto, K. Tsuda, A., \& Hayashi H. (2016). Implementing a flipped classroom in teachning second language pronunciation: challenges, solutions and expectations. In C.-H. Lin, et al. (Eds.), Preparing Foreign Language Teachers for NextGeneration Education (pp. 114-129). Hershey: IGI Global.

Zervas, P., Chatzistavrianos, K. \& Sampson, D. (2014). Towards modelling teachers' ICT competence profile in Europe. In R. Huang, et al. (Eds.), ICT in Education in Global Context: Emerging Trends Report 2013-2014 (pp. 163-184). BerlinHeidelberg: Springer. 
